\title{
Judicial Notice: The Very Texture of Legal Reasoning
}

Susan G. Drummond

Osgoode Hall Law School of York University, sdrummond@osgoode.yorku.ca

\section{Source Publication:}

Canadian Journal of Law and Society/Revue Canadienne Droit et Société. Volume 15, Issue 1 (2000), p. 1-38.

Follow this and additional works at: https://digitalcommons.osgoode.yorku.ca/scholarly_works (c) (i) $(9)$

This work is licensed under a Creative Commons Attribution-Noncommercial-No Derivative Works 4.0 License.

\section{Recommended Citation}

Drummond, Susan G. "Judicial Notice: The Very Texture of Legal Reasoning." Canadian Journal of Law and Society 15.1 (2000): 1-38.

This Article is brought to you for free and open access by the Faculty Scholarship at Osgoode Digital Commons. It has been accepted for inclusion in Articles \& Book Chapters by an authorized administrator of Osgoode Digital Commons. 


\section{Judicial Notice : \\ The Very Texture of Legal Reasoning}

\section{Susan G. Drummond}

The doctrine of judicial notice is philosophically intriguing in its own right and exciting because of the new ground that it is breaking in Canadian law. It also happens to be a confusing and confused part of the law. The doctrine seems to careen between saying something so obvious that it says nothing at all and threatening some of the very foundations of legal orthodoxy. Some of the ambiguity in the doctrine is caused by a wider epistemological disorder.

Another difficulty in getting a grasp on it is that the manner in which it is construed as ideologically-charged. It seems to either subtly promote judicial activism or counsel judicial restraint. One version of the doctrine locates the intelligibility and legitimacy of law close to the heart of the political community; another prizes law for its ability to remain politically transparent by virtue of its prior fidelity to a venerable professional tradition. Deeper commitments seem to be at stake, ones that are incommensurable with each other, calling for articles of faith where the bedrock of justifications has been reached. Without further justification, the doctrine is placed in very distinct spots in legal theory, turning up in some obscure and rarely visited corner, or confronting us face on as one of the central entrances to a understanding of law. Significant and far-reaching consequences flow from the scope and place that the doctrine is given in the legal order. What $I$ hope to do here is to eliminate some of the incoherencies in the doctrine in order to allow it to operate with greater incisiveness.

Recently the doctrine of judicial notice has been advancing onto the ground of family law. In an obiter in Moge v. Moge, Madame Justice L'Heureux-Dubé remarked that on the basis of a weighty corpus of social scientific research into the feminization of poverty "the general economic impact of divorce on women is a phenomenon, the existence of which cannot reasonably be questioned and should be amenable to judicial notice." The case puts considerable emphasis on compensation as an objective of spousal support alongside the other three objectives of

\footnotetext{
'Moge v. Moge (1992), 43, RFL (3d) 345 [hereinafter Moge].

Canadian Journal of Law and Society / Revue canadienne droit et société, Volume 15, no. 1, 2000, pp. 1-37.
} 


\section{Susan G. Drummond}

the Divorce $A c t^{2}$, significantly narrowing the scope of an antecedent jurisprudence that placed inordinate emphasis on the promotion of economic self-sufficiency following divorce. By virtue of this latter emphasis in statutory interpretation, couples were encouraged to extricate themselves from their former spouses, financially and emotionally, as soon as possible. Moge, on the other hand, recognizes the complex and enduring economic disadvantages suffered by spouses (principally wives) due to the distribution of childcare responsibilities and domestic services and as such it has been celebrated as ushering in a new model of spousal support. It has disconcerted those who had come to take for granted the fit-for-tat of the self-sufficiency model, the 'fish or cut bait' response to women's demand for equality. It is not clear what role the doctrine of judicial notice played in turning the tide, nor what role it could play. Part of this uncertainty comes from ambiguities in the doctrine itself, and it is to an elucidation of these issues that I will now turn.

\section{What is judicial notice?}

Thayer, one of the first systematic writers on the subject, places the subject of judicial notice at the very beginning of his treatise on evidence as the first chapter. Not only does it occupy this first principles place in his doctrine, its scope is much wider than the law of evidence, undergirding it. "Where about in the law does the doctrine of judicial notice belong?" Thayer asked in 1900.

Wherever the process of reasoning has a place, and that is everywhere. Not peculiarly in the law of evidence. It does, indeed, find in the region of evidence a frequent and conspicuous application; but the habit of regarding this topic as a mere title in the law of evidence obscures the true conception of both subjects. That habit is quite modern. ... The subject of judicial notice... belongs to the general topic of legal or judicial reasoning. It is, indeed, woven into the very texture of the judicial function. In conducting a process of judicial reasoning, as of other

${ }^{2}$ Spousal support should give effect to the three objectives of spousal support orders defined in s. 15(6) and s" 17(7) of the Divorce Act, R.S.C. 1985 ( $2^{\text {nd }}$ Supp.) c. 3, which are to:

a) recognize any economic advantages or disadvantages to the spouses arising from the marriage or its breakdown ;

b) apportion between the spouses any financial consequences arising from the care of any child of the marriage over and above any obligation for the support of any child of the marriage;

c) relieve any economic hardship of the spouses arising from the breakdown of each spouse within a reasonable period of time. 
reasoning, not a step can be taken without assuming something which has not been proved; and the capacity to do this, with competent judgment and efficiency, is imputed to judges and juries as part of their necessary mental outfit. $^{3}$

Judicial notice is omnipresent in the law for Thayer. It is backed by the common sense and ordinary experience that judges bring to the courtroom. It is, in part, comprised of unproven background elements without which not a step of proof on the foreground can be taken. Judicial notice embodies what everybody knows, and what every good judge knows: ordinary usages and practices of courts, general principles and rules of the law of the court's jurisdiction, ordinary meaning and the use of vernacular language, the ordinary data of human experience, local knowledge, the ordinary habits of human beings... . The judge is presumed to be:endowed with this sense that is commonly held, is obliged to so endow herself if there is a pertinent lacuna. On this view of the doctrine, the judge is active and inquisitive. She has a large discretion to judicially notice and has an obligation to inform herself independently of the adversaries of litigation.

Because the judge figures positively in this process, is obliged and presumed to take it upon herself to incorporate the sense that is commonly held, and proffers an authoritative understanding of it, the exercise of judicial notice is open to scrutiny. On Thayer's understanding of the doctrine, taking judicial notice does not imply that the matter is indisputable. Tentatively, the noticed fact raises prima facie evidence of the fact. It is presumed by the judge until there is a reason to think otherwise. It can be countered by one of the parties to the dispute. It can be countered on appeal. It can be countered in subsequent cases where any of the parties can meet the prima facie evidence that masqueraded as common sense by presenting their reasons for thinking otherwise. And it can be countered by changes in or alternate understandings of common sense that plead against prior assertions. On Thayer's approach, the judge is a bold and active presence, and yet, in virtue of the openness of judicially noticed facts to dispute, also a tentative and limited authority.

Writing half a century later, Morgan radically narrowed the scope and application of the doctrine ${ }^{4}$ In part he did so by delimiting it negatively. Front and centre for Morgan was the adversarial system and the rules of evidence that shore it up. Each party to a dispute presents evidence to support his or her version of the facts and the court in general

\footnotetext{
${ }^{3} \mathrm{~J}$. Thayer, A Selection of Cases on Evidence at the Common Law (Mass: Charles W. Server \& Co., 1982) at 19-20.

4 E. J. Morgan, "Judicial Notice" (1944) 57 Harvard Law Review 269-94.
} 
the rules of evidence that shore it up. Each party to a dispute presents evidence to support his or her version of the facts and the court in general acts as an impartial arbiter to hear and determine the issues. The court has no machinery for discovering, without the aid of the parties, matters of fact that are disputable and disputed, nor is an independent investigation into the disputed facts by the court permitted. The trier of fact has no duty and no license to discover the truth of disputed facts, retaining only the obligation to decide what the facts most credibly appear to be as disclosed in the material submitted - such as it is.

The doctrine of judicial notice is an exception to these principles of evidence. Whereas the judge is normally transparent in matters of fact, a neutral medium for the evidential laws that govern the process, the judge takes on a fleeting human presence in facts judicially noticed. The purpose of this momentary presence in the adversarial traffic of facts is to swoop down and scoop irrelevant facts out of the arena of dispute so as to minimize the presentation of moot issues and foreclose the claim or defense of false issues, thus expediting the process. The irrelevancy of this particular order of facts arises in virtue of the fact that no reasonable person could hold them in dispute. The range of matters which are amenable to judicial notice are propositions, legal and extra-legal, which are so probably true as to be notoriously indisputable amongst reasonable men. The judge, as the arbiter of what is notoriously indisputable among reasonable people, immunizes these facts from proof or disproof by formal evidence in taking judicial notice. This immunization does not operate as a presumption. It is a manœuvre that forecloses further evidence. The judge operates, in this case, as a virtually unlimited authority with limitations imposed only from within the legal hierarchy. Judicial notice can only be contested on appeal and invalidated if it can be demonstrated that the criteria for the application of judicial notice were not present (the fact was not notorious, the sources to establish the fact were not indisputable...). As judicially noticed matters operate in the domain of fact, not law, they have no precedential value. Judicial notice and stare decisis perform wholly distinct functions in law.

This is a slightly caricatural presentation of the two extremes of the doctrine of judicial notice:

i) judicial notice as the disputable background to law, including the law of evidence - a tentative depiction of the firmament illuminating the law;

vs

ii) judicial notice as the very intermittent demonstration of judicial authority - an exceptional departure from the principled search for truth through proof. 
Since Morgan, the doctrine has gone through a series of elaborations pulled back and forth between either of the epistemological poles that these two versions stake out. While, according to legal commentators, ${ }^{5}$ conventional wisdom in Canadian law has tended to favour Morgan's narrow reading of the doctrine, there is a parallel trend that has recuperated Thayer and fine-tuned his analysis. This trend appears to be in the ascendancy at the moment and is changing both the social and legal meaning of the doctrine.

Reliance upon L'Heureux-Dubé's comments in Moge have given the Thayer model something akin to, if not identical to, precedential status as a statement of current Canadian law. Family court judges in the wake of Moge have been using Moge precedentially as good legal authority for recognizing the feminization of poverty as a background fact for spousal support determinations. ${ }^{6}$ This kind of precedent operates at two levels: Concretely, Moge is good legal authority for a change in the way that spousal support is viewed. But a precedent is also being set for a shift in the doctrine of judicial notice. The case is turning out to be good legal authority for a more general proposition. If the feminization of poverty, a matter of fact, is now treated as something that does not need to be formally proved but is taken to have made its prima facie case in Moge, then the case and the use being made of it is simultaneously endorsing the view that judicially noticed facts are pulled out of the domain of fact and into the domain of law. It looks like a new precedent about judicial notice is emerging in the common law, overtaking the old model.

As well, not a few of the subsequent cases are treating the virtually noticed fact of the feminization of poverty in Moge as a legal presumption, amenable to dispute by the parties. ${ }^{7}$ This emerging practice of treating judicially noticed facts as prima facie evidence goes against the grain of legal commentators such as Sopinka and Schiff, two Canadian authorities on evidence, who hold it to be conventional wisdom in Canadian law that it is in the nature of judge-initiated noticed facts that they are radically removed from the formal proceedings. ${ }^{8}$ Paradoxically, the manner in which this transformation of conventional

${ }^{5}$ See J. Sopinka, S.N. Lederman \& A.W. Bryant, The Law of Evidence in Canada (Toronto: Butterworths, 1992) [hereinafter Sopinka] ; S. Schiff, Evidence in the Litigation Process, $4^{\text {th }}$ ed. (Toronto: Carswell, 1993); Report of the Federal/Provincial Task Force on Uniform Rules of Evidence (prepared for the Uniform Law Conference of Canada) (Toronto: Carswell, 1982) [hereinafter "Federal/Provincial Task Force"].

${ }^{6}$ L. H. Wolfson, D.S. Melamed \& S.J. Morris, "The Use of Judicial Notice in the Wake of Moge v. Moge" (1994) 11 Canadian Family Law Quart. 159, which provides an extensive list of related judicially notices facts in family law in the wake of Moge.

${ }^{7}$ See appendix B, ibid.

${ }^{8}$ Supra note 5. 
legal wisdom is taking place seems to add justification to the model of judicial notice that Thayer, and now L'Heureux-Dubé, are promoting, whereby the judge (Supreme Court Justice L'Heureux-Dubé in this case) is an active, inquisitive presence of tentative authority whose claims are eligible to be limited by the parties to a dispute by rebuttal evidence, limited by the legal hierarchy through appellate investigations into the appropriate use of criteria, limited by subsequent case by case responses to the prima facie assertion of common sense, and open to limitation by changes in or an alternative understanding of common sense pleaded against prior assertions. This is the Thayer model of judicial notice in action, justifying itself, showing that the doctrine belongs to the general topic of legal or judicial reasoning and is woven into the very texture of the judicial function.

This subliminal re-writing of the doctrine of judicial notice has been facilitated by doctrinal shifts which have qualified and requalified the Morgan doctrine, which entered into law almost verbatim in the United States in the Model Code of Evidence and the Uniform Rules of Evidence drafted by Morgan. It does so in a manner that brings it back, half a century later, to Thayer. L'Heureux-Dubé recapitulates this evolution in her legal commentary on judicial notice subsequent to the Moge obiter called 'Re-examining the Doctrine of Judicial Notice in the Family Law Context' - an article that both puts out a tentative claim about the doctrine of judicial notice and which also happens to stand as an equally authoritative source on the law of judicial notice as the doctrinal writers whom she cites therein as authoritative on the question. It stands as good authority until good reasons are advanced to throw it into question. It both tells us about the place of judicial notice and simultaneously shows us how it works.

The first significant qualification of the Morgan doctrine came with Davis' 1955 article $^{10}$ on judicial notice. His recharacterizations of Morgan have been taken up as seminal by contemporary writers on the subject, and by courts in the United States and Canada. What is almost universally accepted now is the distinction he makes between adjudicative and legislative facts. In the matter of adjudicative facts, Davis is in agreement with Morgan about the appropriate attitude of the judge. Adjudicative facts are those facts that are personal to the immediate parties before the court. They relate to their actions, their activities, their possessions, involving determinations of 'who did what, where, when, how, and with what motive or intent'. "Determinations on

9 C. L'Heureux-Dube, "Re-examining the Doctrine of Judicial Notice in the Family Law" (1994) 26 Ottawa Law Rev. 551 [ hereinafter L'Heureux-Dubé].

${ }^{10}$ K. C. Davis, "Judicial Notice" (1955) 55 Columbia Law Review 945 [hereinafter Davis].

"32B Am. Jur. 2d, Federal Rules of Evidence § 32. 
these questions should be treated by the parties through formal methods of proof. With this order of fact, independent judicial investigation is inappropriate. The judge is properly passive with regard to these facts, active only with regard to the proper disposition of the law in regard to process and substance.

Legislative facts, however, do not invite the same treatment. Legislative facts are those that aid the court in determining the content of the rules which they are mandated to apply. They are general propositions, not only affecting the particular parties before the court but having ramifications on the interests of future litigants.

While it is accepted that legislative facts are established outside of the formal tableau of proofs, it is the exact content of legislative facts that is undetermined. Davis' scope is very wide indeed and close to Thayer's broad understanding of legal reasoning itself. Legislative facts are those "which help the tribunal to determine the content of law and policy and to exercise its judgment or discretion in determining what course of action to take." ${ }^{2}$ The law is a creative process in this model, the judge charged with roaming far and wide in the wise execution of his or her creative duty, and judicial notice structured so as to facilitate the process. As aids to judicial law-making, legislative facts include social and economic facts as well as propositions about the applicable law in the jurisdiction. Davis, like Thayer, includes what I shall call, after Wittgenstein, "form of life" matters in the category of social facts which are legislative. By "form of life" I mean the structure of reasoning in a given community that lends determinations on the foreground their second-nature - their naturalness - as well as their sense of limits and sense of the transgression of limits. Thayer called these elements those that are 'woven into the very texture of the judicial function'. This is how Davis describes these "form of life" facts:

A human being is probably unable to consider a problem whether of fact, law policy, judgment, or discretion without using his past experience, much of which may be factual and much highly disputable. ... Judge and administrative officers should make their policy choices on the basis of all relevant facts, even though the kind of facts that usually influence policy choices are often too elusive to be captured and penned up within a formal record. The wisdom we seek in judges and in administrative officers is made up of multifarious ingredients that often defy identification and usually defy separation from other ingredients - knowledge of specific facts, understanding of

${ }^{12}$ Davis, supra note 10 at 952. 
general facts, prior experience in trying to solve similar problems, mental processes such as logic or reasoning and mental processes such as appraising or estimating or guessing, formulation and application of notions of policy, imagination, inventiveness and intuition, emotional reactions and emotional control. ${ }^{13}$

While the Canada Evidence Act ${ }^{14}$ narrows legislative facts to recognition of legislation and common law in effect in the jurisdiction, the aborted 1970s Evidence Code of the Canada Law Reform Commission's Report on Evidence and the aborted 1980s Uniform Evidence Act took pains to broaden the scope again to approach Davis' standard. Both reform proposals seek to include in the domain of legislative fact those elusive "multifarious ingredients that often defy identification and usually defy separation from other ingredients." In their comments on the Evidence Code, the Law Reform Commission seeks to include by illustration a range of background facts not requiring proof. So, for example,

... when a witness testifies that he observed a car in a lot, the judge or jury will necessarily associate an object with the word "car", even though no evidence was introduced as to its meaning. Evidence would not normally be offered at a trial to prove the proposition that a car travelling eighty miles per hour cannot stop within a distance of ten feet; that a horse is a four-legged animal; that a gun is a dangerous weapon; or that the sun does not shine at midnight in Ottawa. It would consume an endless amount of time if all these facts had to be independently proved. Therefore, the parties are entitled to assume that the trier of fact, be he judge or juror, will bring his common sense and experience to bear in reasoning about the evidence presented. ${ }^{15}$

In these comments, it is important to notice that the Law Reform Commission is drawing attention to an implicit process of familiar recognition that happens all the time and that keeps the evidential quest in line. These are matters that are not in question in the trial process. They are taken-for-granted. I will also argue that it is grammatically incorrect to say that these are things that "everybody knows" or that they are "facts" or "assumptions" but rather that these are things that are understood. I will also argue that something hangs on this rather quibbling distinction that I am drawing.

\footnotetext{
${ }^{13}$ Ibid. at 949.

${ }^{14}$ Canada Evidence Act, R.S.C. 1985, c. C-5.

${ }^{15}$ Canada, Report on Evidence (Ottawa : Canada Law Reform Commission, 1975) at 103.
} 
The Task Force report on the Uniform Code of Evidence similarly recommends that judicial notice be expanded to legislative facts which have this "form of life" quality to them. The reporters were of the unanimous view that "the terminology of 'legislative' fact is neither well known nor well understood" and that the concept "related not so much to facts that have to be proven as to the mental context in which the judge views the case. Legislative facts may be thought of as social facts which constitute the fund of knowledge the judge has and upon which he must draw in determining the case." Echoing Thayer they note that the concept "is part of judicial reasoning rather than of evidence."

This "form of life" understanding of legislative facts also strikes a chord with L'Heureux-Dubé who, in citing Sopinka's description of judicial notice, places greatest emphasis on the notion that "tacit judicial notice ... surely occurs in every hearing [and is] indispensable to the normal reasoning process." 16 In her own words, these fundamental facts "comprise a prism of personal experience and understanding through which judges and jurors, as factfinders, both perceive and interpret that which is put before them." 17

This understanding of legislative facts as including "forms of life" has implications for what exactly the procedure is for taking judicial notice. There is often an obfuscation in the way that the phrase is used. In the event that judicial notice is taken at the request of one of the parties, there is less room for confusion. Ideally, pursuant to the request, the judge should hear arguments or evidence before taking notice of a matter. Once notice is taken, no further evidence can be tendered on that issue at trial.

The more interesting, and confused, case is what it means for a judge to take judicial notice on his or her own initiative. It is here that there is a grammatical obfuscation between an explicit and an implicit procedure. Correct procedure hinges very much on which view one takes about the matters that are amenable to notice. On the one hand, it seems patently obvious that, for the doctrine to be actually doing something, the judge must notify the parties that notice is being taken of some matter and must specify precisely what that matter is. Delisle goes further and characterizes the necessity for this openness as a matter of natural justice. ${ }^{18}$ Certainly the provisions of Morgan's Model Code allow no exception to the requirement that the parties be given advance notification of intent to take judicial notice. This seems all the more reasonable given that, on the narrow reading of the doctrine, judicially

${ }^{16}$ L'Heureux-Dubé, supra note 9 at 559.

${ }^{17}$ Ibid.

${ }^{18}$ R. J. Delisle, Evidence: Principles and Problems, $3^{\text {rd }}$ ed. (Toronto: Carswell 1993) at 259. 
noticed facts are only inconclusive on appeal. Surely if the appeal is to have a ground for examining the propriety of that which has been judicially noticed, then there must be no doubts about whether judicial notice took place or not. And yet, it is not at all clear that this is always what is meant by "taking judicial notice".

There is a use of the phrase "to take judicial notice" that occurs over and over again in the literature and that is consistent with the understanding that the procedure can be implicit. Indeed the process could be subliminal. The judge, let alone the parties, may even be utterly unaware that they are taking notice. Thayer suggests that this is what is happening when he remarks that "... in conducting a process of judicial reasoning, as of other reasoning, not a step can be taken without assuming something that has not been proved." ${ }^{\prime 19}$ But these unproved assumptions that guide the process of judicial reasoning are not, each and every one of them at every turn of mind, everpresent before the mind's eye. And yet, they are part of the omnipresent legal reasoning that Thayer includes as part of judicial notice.

Davis takes this analysis further and underlines that this implicit process is, in large measure, exactly what he means by the procedure of taking judicial notice and he underlines that it in fact is what happens in court all the time. Rather remarkably, he suggests a modification to the Model Code along the following lines:

Because all thinking by judges and by officers about questions of fact and law, policy and discretion necessarily involves the assumption of many facts that have not been proved, perhaps ninety-nine out of a hundred extra-record facts are so obvious that no one would conceivably want to challenge them. Therefore, the necessary and proper procedure is for the judge or the officer to go ahead and notice them, without even mentioning that assumptions are made about the meaning of the word "the", that water runs downhill, or that the United States has a government. ${ }^{20}$

The reading of what it means to "take judicial notice" that construes it as most commonly an implicit process is by no means a marginal or antiquated take on the meaning of the words. The Provincial/Federal Task Force on the Uniform Code of Evidence remarks that "... often the doctrine of judicial notice takes hold tacitly rather than explicitly."21 They cite Nokes as saying that "in many cases no reference is made during the trial to [judicial notice] founded on common knowledge; if the

\footnotetext{
${ }^{19}$ Thayer cited in Davis, supra note 10 at 949.

${ }^{20}$ Davis, supra note 10 at 978.

21 "Federal/Provincial Task Force", supra note 5 at 45.
} 
fact is relevant, everyone in court will assume that rain falls, for example; and there is no ascertainable limit to the matters that are thus silently noticed by both judge and jury."22 And L'Heureux-Dubé, in her 1994 article, incorporates Davis' approach into her argument by citing his comment that background facts "are frequently 'noticed' despite the absence of pertinent evidence in an invisible process by which a judge or juror relies upon "beliefs" ... which he reasonably thinks he shares with other intelligent persons as to the general nature of things... Judicial ... notice of background facts is pervasive, occurring 'inconspicuously and interstitially' as an inevitable part of the adjudicative decision making process." ${ }^{23}$ She emphasizes that it is more uncommon that these background facts get flushed to the surface of awareness, more common that they remain in the interstices of thought and understanding.

Both the Davis/Thayer and the Morgan doctrine are in agreement that the discretionary power of the judge to take judicial notice is subject to appeal by reviewing courts. But the implications of Davis' thesis about procedure are really quite remarkable at the appeal level, especially when consideration is given to the recent emphasis on making legislative facts matters of law and hence appropriate questions for both precedent and an appeal tribunal, a development in the law to which I will return. If we imagine that what the judge simply takes for granted are actually implicitly noticed legislative facts, then a new ground for appeal opens up. There is, on this thesis, an opening to contest, at the appeal level, those taken-for-granted forms of life that can be shown to have had an impact on the inference-drawing process.

One could argue at the appeal level that what was taken as a form of general legal reasoning was in fact a reflection of one particular legal sensibility. One could argue that a judge took something to be a universal feature of human reasoning when in fact it merely reflects a local understanding. One could argue that a judge has not determined matters in accord with the sense that is commonly held, that is, the sense of the relevant local community. One could argue that the judge took insufficient notice of the way that local history or geography or culture or common sense is in contention with his or her common sense. One could argue these and related things at the appeal level even though the judge never acknowledged - nor may indeed have been aware - that these were the background assumptions which enabled him or her to come to a determination on the foreground.

${ }^{22} \mathrm{lbid}$. at 45-6.

${ }^{23}$ L'Heureux-Dubé, supra note 9 at 558-59. 
This critical drift into particularizing the sensibilities of judges and opening that sensibility up for review finds support in L'Heureux-Dubé's article in which she points out that

[t]hese fundamental facts comprise a prism of personal experience and understanding through which judges and jurors, as factfinders, both perceive and interpret that which is put before them. Not all factfinders, however, will perceive the same circumstances in the same way. Moreover, while the prism held by most factfinders may constitute a perfectly adequate analytical framework in most situations, in certain contexts it may not accord with reality, and may therefore impede rather than advance the quest to find facts in a way that is reflective of how people really experience the world. ${ }^{24}$

Delisle specifies some of the more notorious 'prisms' which get judicially noticed when he remarks that "we need to recognize that "common sense and experience," judicially noticed, and hence relevance, may vary depending on the judges' culture, gender, background, education, social origin and age." ${ }^{25}$ On Davis' model, all of these implicitly noticed matters of agreement in judgment are challengeable on appeal on demonstration that the shared background that gives rise to a particular inference at trial is not universally shared, the judgment therefore suspect.

As I indicated above, the implications on the appeal process of the Davis/Thayer view that judges can and do 'take judicial notice' implicitly are consolidated by recent developments on Davis' seminal distinction between adjudicative facts and legislative facts. The most interesting elaboration on the Davis distinction comes from recent work by American writers Monahan and Walker who are cited favourably and at length by L'Heureux-Dubé in her article on judicial notice in the domain of family law. Their work primarily deals with the incorporation of social science research into the litigation process but I shall focus on their remarks about the precedential status of this material once it is judicially noticed.

Monahan and Walker promote a new paradigm to fine-tune Davis's legislative/adjudicative fact distinction. They propose a tripartite schema: social authority, social framework, and social facts. The third category, "social facts", effectively overlaps with "adjudicative facts" as those facts used to resolve a dispute specific to the proceedings between

\footnotetext{
${ }^{24}$ Ibid. at 559.

${ }^{25}$ Delisle, supra note 18 at 258.
} 
particular parties. ${ }^{26}$ Social authority overlaps with Davis' “legislative facts", and "social framework" is a hybrid of the two.

The social authority category includes social science research that relates to the judicial lawmaking process. It is comprised of empirical propositions of a general nature which go to the social authority underlying a rule of law applicable to many parties. ${ }^{27}$ Social framework facts, on the other hand, are those empirical propositions offering general research results as a context or frame of reference to assist the court in deciding specific factual questions. Included in the latter category would be the social science research into battered women's syndrome or the findings of research on the feminization of poverty where research is not specifically commissioned for the particular parties to a dispute but rather inferences are drawn about the particular parties on the basis of the off-the-rack research.

For the purposes of this discussion, what is interesting is that Monahan and Walker propose that both social framework facts and social authority facts be granted precedential authority and form the basis of law. Social authority facts take on this precedential status as prima facie evidence. Even unsupported empirical assertions, if otherwise plausible, can be treated like rules of law. Empirical judgments remain provisional. Courts incorporate these judgements as good law, while remaining attentive to changes not in judge-made or statutory law, but in empirical evidence. Changes in empirical findings would compel a reconsideration of what, until then, had stood as law, with no requirement for olympian efforts to distinguish it.

Judicial notice, in this case, is not different from stare decisis in respect of noticed facts being incorporated into the common law and guiding future cases in requiring departures to be justified. But there is a way in which this view of judicially noticed facts departs from the doctrine of stare decisis. Stare decisis not only puts future parties on notice of the law, it simultaneously serves to consolidate the integrity of the legal system and constrains the manoeuverability of future courts.

${ }^{26}$ The leading case for treating social scientific material as adjudicative or social fact is Processed Plastic v. Warner Communications, 675 F. $2^{\text {nd }}, 852\left(7^{\text {th }}\right.$ Circuit, 1982) in which the plaintiff adduced empirical testing on market responses to that particular car design in question to prove that trademark had been infringed. See L. Walker \& J. Monahan, "Social Frameworks: A New Use of Social Science in Law" (1987) 73 Va. L. Rev. 562 [hereinafter Walker \& Monahan].

27 Walker and Monahan cite the leading case of Unites States v. Leon 468 U.S. 897 (1984) which decided whether good faith violations of police search warrants violated the fourth amendment where social scientific proof was adduced to show statistically that in fact police did not take license to abuse due process when courts did not overturn good faith failures to comply with the requisite process for search and seizure warrants. Ibid. at 562 . 


\section{Susan G. Drummond}

This understanding of judicial notice loosens up those constraints, or rather hands them over to a different order of constraint. An empirical argument could overturn a legal precedent without making reference to statute or jurisprudence but could directly reproach a prior empirical finding. It is tempting to say in this case that the integrity of the legal order would be maintained less by reason of authority than by authority of reason, where reason, in this case, is social scientific. Construing this as a move from the constraint of tradition to the constraint of reason is misconceived, however, because all forms of reasoning are imbedded in traditions and legal traditions are woven through with, and supported by, their own particular forms of reasoning. I will return to this point. It might be more accurate to say that on this model of judicial notice the constraints on law move from the forms of reasoning traditionally used in law to the forms of reasoning familiar to other human enterprises.

That this order of judicially noticed facts - what Monahan and Walker call social authority facts - take on the status of precedent is not particularly novel. Sopinka and Lederman remark that "the fact that a certain fact or matter has been noted by a judge of the same court in a previous matter has precedential value" 28 and advise counsel and court, therefore, to examine the case law record to avoid proving acknowledged facts. More adventurous are the arguments of Monahan and Walker to establish the precedential status of social framework facts in order to bypass the timely and costly process of re-proving these general social science findings anew at each case. This would widen the scope of those facts elevated to law through the process of judicial notice.

The argument that they present to justify the elevation of these facts to law through judicial notice operates via an analogy between the doctrine of common law precedent and the manner in which social scientific material is made authoritative. The criteria courts should use in determining whether to notice a social scientific fact would be virtually the same criteria internal to the scientific community in elevating certain social scientific material to seminal and authoritative status and disregarding other material as unreliable and unpersuasive. This process in the social scientific community happens to mimic, they remark, the process whereby certain cases are certified as reliable and persuasive in the legal community. Thus they argue that:

[j]ust as a case reviewed by a court high in the appellate structure has more weight as precedent than an unreviewed lower court opinion, so the degree to which a researcher's work has been subject to the critical review of his or her peers in the scientific community is an important index of the trustworthiness of the results. The publication of

${ }^{28}$ Sopinka, supra note 5 at 977. 
research in journals with independent scientific editorial boards, for example, is one way to ensure that some such review has taken place.

The extent to which courts will accord a decision precedential value depends not only on the level of court that issued it, but also on the quality of reasoning revealed in the opinion itself. Decisions viewed as "well reasoned" are more likely to be taken as authoritative than are decisions in which the inferential links between the principles invoked and the holding reached are difficult to discern or are logically flawed. In the context of social science research, a well reasoned study is one that possesses "validity". To have "high" validity, a study must rule out (or control for) competing hypotheses that may account for an observed state of affairs. Social scientists design their studies to minimize factors that could compromise validity and make the results of the research equivocal or "poorly reasoned". ${ }^{29}$

These criteria - whether the research has been tested by extensive peer review, whether valid methods were employed, how it falls within a substantial line of pertinent inquiries - should be used by the judge to determine whether the empirical propositions should be noticed.

This list of criteria should resonate with those who are familiar with Alisdair MacIntyre's concept of a practice. And it is here that I return to my point above about forms of reasoning and what makes certain reasons authoritative. MacIntyre defines a practice as

any coherent and complex form of socially established cooperative human activity through which goods internal to that form of activity are realized in the course of trying to achieve those standards of excellence which are appropriate to, and partially definitive of, that form of activity, with the result that human power to achieve excellence and human conceptions of the ends and good involved, are systematically extended. ${ }^{30}$

MacIntyre's remarks about standards of truth being internal to the practice is also resonant with the tests which Monahan and Walker are promoting in limiting law's quest for truth through the evidential process and expanding other forms of reasoning. Monahan and Walker argue that social framework material should be given the status of a legal rule

${ }^{29}$ Walker \& Monahan, supra note 26 at 589-90.

${ }^{30}$ A. MacIntyre, After Virtue : A Study in Moral Theory (Notre Dame: University of Notre Dame Press, 1981) at 187. 
through judicial notice. This legally authoritative status should be reversible by the presentation of new empirical research that upsets the expectations established by the earlier research and has been weighed in the crucible of social science practice. This is a plea that other forms of human excellence take their place in law and that sources other than the narrow, self-replicating traditions of legal inquiry be considered as authoritative in law. The manner in which they have articulated their plea does not suggest a rock hard universal epistemological foundation for determining which facts should be elevated to law. Rather they adopt a community standard approach which takes its measure of excellence what MacIntyre calls 'Internal goods' - from within the socially established cooperative human activity at issue. This measure of excellence, as MacIntyre points out, is only "identified and recognized by the experience of participating in the practice in question. Those who lack the relevant experience are incompetent thereby as judges of internal goods." 31 Monahan and Walker's suggestion is to delegate the adjudicative process in these matters to those who have mastered the relevant rules and experiences through diligent participation in the practice.

The Walker and Monahan proposal, then, extends the body of judges competent to adjudicate particular disputes beyond the legal profession. They do this in a manner that does not just hand the matter over to experts. The test that they have set up for social framework matters to qualify for judicial notice - peer review, validity, location within a substantial line of inquiry - is more like handing a measure of the adjudicative process over to the communities in which the experts excel. The individual expert has no authority to make authoritative statements independent of the community in which he was formed. Again, MacIntyre speaks well to this point. He says :

A practice involves standards of excellence and obedience to rules as well as the achievement of goods. To enter into a practice is to accept the authority of those standards and the inadequacy of my own performance as judged by them. It is to subject my own attitudes, choices preference and tastes to the standards which currently and partially define the practice. Practices of course, as I have just noted, have history : games, sciences and arts all have histories. Thus the standards are not themselves immune from criticism, but nonetheless we cannot be initiated into a practice without accepting the authority of the best standards realized so far. ${ }^{32}$

\footnotetext{
${ }^{31}$ Ibid. at 188-89.

${ }^{32}$ Ibid. at 190.
} 
The expert is not a self-made person and nor can she be a self-proclaimed expert. The authority of her reasons comes from obedience to standards external to her. Having originally accepted the inadequacy of his or her performance as judged by those community standards, he or she may excel and generate, through diligence, devotion, or even sheer brilliance, one of those formulations which become the best standards realized so far. In that event the expert will speak superlatively for the community, not for him or herself.

The experts to whom Monahan and Walker would extend the adjudicative role are non-elected representatives of a community. They do not always compel because they represent a consensus or even a majority in the community. The qualifications of the experts are not democratic in that sense. Not infrequently peer review recognizes them because they have subverted the conventional pieties of the community and re-written the historically accepted standards of excellence internal to the community. Having been long obedient to the sense of the community, the expert pushes the limits of the sense that is commonly held, sometimes transforming it. Not infrequently they are at the forefront in artfully reformulating some of the community's most contentious issues. In this they are not unlike judges.

Monahan and Walker do not only extend the adjudicative role to non-legal experts and their communities, they also see a much more active role for the judge than the impartial and passive observer of the factual world that Morgan envisaged. The underlying assumption of their argument is that courts should treat social science facts in the same manner that they treat legal precedent. One court's conclusions about a social framework should affect the judgments of later courts just as one court's conclusions about a matter of law affect later courts. In the event that there is a jury, the judge should manage social framework material in the same way that the law is communicated to the jury - by instruction that they are to apply the social framework given by the court to the facts. But just as it is the responsibility of the court, rather than the jury, to evaluate case precedent, so Monahan and Walker assert, it is the responsibility of the court, rather than the jury, to evaluate social science research. The view supporting independent judicial investigations into those background facts amenable to judicial notice is consistent with the accepted practice that courts are free to carry out their own search for legal authority not signaled by the parties. As social framework and social authority are matters of law on this doctrine of judicial notice, judges should be free to do their own investigations to locate relevant social science studies. Indeed standards of practice impose an obligation upon judges to familiarize themselves with the relevant law, and this 
elevation of social science research to matters of law intimates that the standards of excellence by which judges are judged impose an obligation to be well-informed and intellectually adventurous over a diverse range of interdisciplinary standards of excellence.

This picture of judicial activism is consistent with Davis' emphatic view of the judge as law-maker in need of a broad range of legislative facts to help determine law and policy. And L'Heureux-Dubé's remarks are consistent with this same tradition of judicial activism. She notes :

One of the more significant aspects of Davis's recognition of legislative facts is his implicit acceptance that agencies and judges, in deciding questions of law or policy, essentially perform an active law and policymaking role rather than passively recognizing or discovering law that is dictated by precedent or principle. Although this observation has long been recognized as "conventional wisdom" in the United States, only recently has it begun to take on a similarly irrefutable character amongst Canadian courts and commentators. The way in which the role of the court is perceived can in turn, very much affect the way in which the doctrine of judicial notice is conceptualized. The more courts acknowledge their active contribution to lawmaking, the greater becomes both their duty and their need to lay bare the policy assumptions upon which their decisions are based. ${ }^{33}$

The doctrine promoted by Thayer, Davis, Monahan and Walker, and most recently by L'Heureux-Dubé counterbalances the non democratic authority of judges to make rules of law through judicial notice by an openness to dispute which the Morgan doctrine does not recognize.

The Morgan judge acquires authority through the constitution and that authority is virtually complete on matters of judicial notice which are indisputable except through review by the constitutionally authorized appellate court. According to Morgan, the common law is not open to change as new social authorities and new social meanings bearing on the assumptions constituting judicially noticed facts become available. It is open to change through changes in legislation which courts are called upon to apply and masterly shows the finesse of the standards of excellence internal to the legal community.

The Thayer judge, on the other hand, has limited authority susceptible to review by changing community standards that overtake the basis on which judicial notice was granted. As prima facie evidence, judicially noticed facts stand as good law only until good reasons can be advanced to review them and these good reasons arise from the better

${ }^{33}$ L'Heureux-Dubé, supra note 9 at 558. 
judgement of the community best placed to assess them. The common law is open to challenge by multiple communities generating new and compelling standards of excellence that the judge is professionally committed to recognizing.

Some of these communities will be recent and volatile, with rapidly expanding standards, the community marked more by arguments about membership and about what constitutes the object around which they are grouped in common activity. The social sciences might be a good example of this form of life which, despite its high level of reflexivity and debate about methodology, can identify standard bearers equipped to articulate the most pressing issues and those settled matters which are understood to be well-established. Some communities may be stable for long periods around a complex set of traditions which are so well incorporated by practitioners that they are taken-for-granted and questioned only at the periphery. The physical sciences or Roman Catholic canon law might qualify here. The legal community, at different moments in its long history and on different parameters probably careens between this intense reflexivity over object and methodology that vexes the most astute practitioners, and the community of understanding that poses those settled doctrine that only a neophyte or an eccentric risk their credibility by questioning.

The doctrine of judicial notice is one of those axes about which other settled doctrines spin. The phrases commonly used to fix its contemporary meaning are usually akin to something like "conventional wisdom". Equivalent phrases also abound. Thus Sopinka remarks that :

There has been a lively debate among text writers as to whether a fact which is judicially noticed forecloses any evidence on the point. Some cases support the view that a judicially noted fact raises a factual presumption of prima facie evidence of the fact. On principle, however, it seems that judicial notice is intended to dispense with evidence, assuming the criteria of its application are present. "This appears to be the modern view." [emphasis added ${ }^{34}$

That an expert such as Sopinka declares that something appears to be the modern view adds considerable weight to what the modern view appears to be. Thus the task force on the Uniform Rules of Evidence remarked that "Academic commentators now appear to agree that judicial notice should be given conclusive effect." 35 L'Heureux-Dubé, on the other hand, surely as qualified an expert as Sopinka and as well positioned to

\footnotetext{
${ }^{34}$ Sopinka, supra note 5 at 986.

35 "Federal/Provincial Task Force", supra note 5 at 43.
} 
discern what appears to be the modern view, indicates in her comments cited above that "conventional wisdom in the United States has long recognized the active law and policymaking role of judges and that this view has begun to take on a similarly irrefutable character amongst Canadian courts and commentators." 36 The conventional American wisdom is supported by legal commentators such as Walker and Monahan whose view it is that judicially noticed matters form prima facie evidence that is open to dispute.

Before discussing which doctrine of judicial notice has become authoritative in Canadian Law, I want to return to an unfinished discussion from above. This is the distinction that I drew between those things which "everybody knows" and things that are understood. If this underlying epistemological difference can be clarified for things that are susceptible to judicial notice, then I believe we should have a clearer understanding about which doctrine of judicial notice has been judicially noticed.

\section{Knowledge and understanding}

There are phrases commonly used regarding judicial notice which, I will argue, are grammatically incorrect. They are accompanied by a set of examples that contribute to this grammatical confusion. The most emblematic of those grammatical errors is the phrase "that which everybody knows". The examples given by the Canada Law Reform Commission are typical of the epistemological confusion that I am talking about where they refer, in the passage cited above, to the meaning of the word "car", the fact that a horse is a four- legged animal, the fact that the gun is a dangerous weapon, and the fact that the sun does not shine at midnight in Ottawa. Thayer and Davis are also guilty of this confusion when they talk about those unproven assumptions upon which proof is predicate. In their examples, they too use examples like the meaning of ordinary words, that water runs downhill, or that the United States has a government. There are many other doctrinal writers prey to this obfuscation, but the Thayer/Davis thesis appears to be the most vulnerable.

I will argue that to call these things "assumptions" is grammatically incorrect just as it is incorrect to say that we "know" them. I will also argue that the way that many of the examples are used indicates that it is incorrect to call those matters "facts" and also incorrect to claim that we "know" them. This grammatical confusion, by my reckoning, is the greatest weakness of the Thayer/Davis doctrine; a weakness that almost renders senseless the notion of tacit judicial notice - a wheel turning

${ }^{36}$ L'Heureux-Dubé, supra note 9 at 558. 
idly. I believe, however, that their doctrine can be rescued with an alternative epistemological understanding which leaves in place the notion of implicit judicial notice and even keeps in place many of the examples used to illustrate the understanding.

This revision, I will try and show, yields fairly compelling guidelines for two scenarios when judicially noticed matters should be made open to review and dispute: i) scenarios in which the very structure of legal reasoning can be shown to be biased and ii) scenarios in which special circumstances plead against common sense. This analysis should also give further fuel to the contention that judicially noticed matters should be treated as prime facie evidence amenable to dispute. ${ }^{37}$ The first guideline to come out of this modification of the Thayer/Davis doctrine for when judicially noticed matter should be made explicit is on appeal from implicitly noticed matters. The second is at moments when common sense is in fact in dispute.

The clearest diagnosis of the epistemological disorder to which Thayer and Davis are vulnerable comes from Wittgenstein's work $O n$ Certainty to which he devoted his attentions at about the same time that Davis was writing in the 1950 s. His thinking is a response to G.E. Moore's famous claims that he knew for certain a number of propositions such as "Here is one hand and here is another" and "the earth existed for a long time before my birth" and "I have never been far from the earth's surface". Moore claimed that this rock hard base of certainty served as the foundation for the claim that the external world existed and hence as an answer to the radical skeptic that Descartes raised in the tradition of Western philosophy. The gist of Wittgenstein's argument is that Moore was wrong in thinking that he knew the propositions at all: not because the propositions were false but because the claim to knowledge of them was senseless. He was wrong to claim that he knew them because of the grammar of words such as "know" and "doubt". But the radical skeptic, Wittgenstein claimed, also misunderstood the nature of doubt, knowledge and certainty. Moore was senselessly answering a question from the radical sceptic that could not sensibly be asked.

Wittgenstein's arguments about Cartesian doubt are directly related to his arguments about Moorish certainty. Doubting, he remarks, itself presupposes certainty. He remarks "If you are not certain of any fact, you cannot be certain of the meaning of your words either." "I don't know if this is a hand" presupposes that I know what the word 'hand' means. ${ }^{38}$

${ }^{37}$ The following arguments should be taken to arise against a component of what Monahan and Walker have called "social authority" facts; I take it that their arguments and procedural proposals are compelling for what they have called social framework facts.

${ }^{38}$ L. Wittgenstein, On Certainty (New York: Harper, 1969). 
Cartesian doubt undermines itself since it is so radical that it is bound to call into doubt the very meaning of the words used to express it. If the evil genius is deceiving me about everything, then I am being deceived about the word 'deceive'. Cartesian doubt thus refutes itself. To say that one is doubting in this case is to use the word incorrectly. It functions as nothing more than the verbal utterance of doubt.

The idea that one can be correct or incorrect in using the word doubt suggests that it is not the lone self confronted with an evil genius that could determine the matters susceptible to doubt or to knowledge. The correct use of the word is something that people learn. And in learning when doubts are appropriate and when they are not, the neophyte must begin by accepting certain things as true, taking them for granted in their attempt to discern the areas where questions are pertinent. This also suggests that intelligible doubts presuppose the mastery of practice. It is the practice, what Wittgenstein would call a "form of life", which sets the parameters of intelligible doubts - when doubts are meaningful and when they are without sense. Doubts about the whole "form of life" are not meaningful as doubting is only intelligible within the parameters of taken-for-granted sensibility into which neophytes are formed.

Testing, then presupposes things which are not tested. So, for example, "If I make an experiment I do not doubt the existence of the apparatus before my eyes. I have plenty of doubts, but not about that. If I do a calculation I believe, without any doubts, that the figures on the paper aren't switching of their own accord, and I also trust my memory the whole time, and trust it without any reservation." And here, Wittgenstein makes an empirical observation about reasonable and unreasonable doubts. To doubt all of our calculations is a mark of craziness, not error. "If someone said to me that he doubted whether he had a body, I should take him to be a half-wit. But I shouldn't know what it would mean to try to convince him that he had one. And if I had said something, and that had removed his doubt, I should not know how or why." 39 The procedure of talking someone out of a mad belief - or, for that matter, of a mad doubt - is quite different from that of correcting a mistake. Reasons can be given for a mistake, but only causes for a mental disturbance.

Wittgenstein then turns these observations about doubting toward Moore's claims to knowledge. He asks whether it is possible to doubt the things that Moore claims to know and asserts that there is, in general, no intelligible meaning to the expression "I doubt that this is my hand." It would be like the behavior of someone who checked to see that his calculations did not shift on the page when he was not looking. "If Moore were to announce the opposite of his propositions," Wittgenstein

${ }^{39}$ Ibid. at $\$ 257$. 
points out, "we should think him demented, not mistaken." But if it is not possible to doubt something, to be mistaken in believing it, to inform oneself about it, then one cannot be said to know it. This is part of the way that the word "know" functions in grammar, a grammar that we learned and are not capable of unilaterally modifying. "I cannot possibly doubt that I was never in the stratosphere. Does that make me know it?" Wittgenstein asks rhetorically. Does it make it true?"40 Claims to knowledge of this type are idle. They say nothing at all, though we are tempted to attribute sense to them because they share the same grammatical structure of utterances that, in different context, do make sense. The reasonable man does not have certain doubts, but neither does he make certain claims to knowledge: only someone uninitiated, mad or otherwise unhinged - someone doing philosophy - could be heard to be making claims to knowledge which spin idly within human communities.

That does not mean that instances cannot arise nor be imagined when some of these propositions might be meaningfully uttered. But those would only be in very special circumstances. One could imagine a context in which it might make sense to say "I know that a car travelling eighty miles per hour cannot stop within a distance of ten feet." If car manufacturers were at some point in the future, to start designing cars the best of which could bring a car travelling eighty miles an hour to a full stop in a distance of ten feet five inches in ideal conditions, an expert with extensive knowledge of the most advanced standards in the industry might intelligibly be heard to say "Standard braking distance has been revolutionized in the last several years but I know for a fact that a car traveling eighty miles per hour cannot stop within a distance of ten feet." At a stretch, one could even imagine a context in which it is intelligible to say "I know that guns are dangerous weapons." Imagine, for example, one was amongst a remote people who had never had direct experience with guns but who watched American movies ranging from Star Wars and Star Trek to Rambo and assumed that guns were like the fantastical swords that Darth Vadar wielded - artifacts of the Hollywood imagination - until an American adventurer visited them and corrected them about guns. If the people had been under this mistaken impression for a long time, naively delighted by the imagery even, they might turn to a second American adventurer with their skepticism and then she might intelligibly state "Yes I understand that you believe that guns are fictions of the American imagination, but I know for a fact that guns are dangerous weapons." Here might be a case where such a claim makes sense. But these are very specific and unusual circumstances. It is hard to

${ }^{40}$ Ibid. at $\$ 222$. 
imagine any kind of a general context in which the claim to such knowledge makes sense, precisely because it is difficult to imagine any general kind of context in which grounds would be present to doubt. The mental exercise of searching for special circumstances is even more difficult for claims to knowledge like "I know the horse is a four-legged animal" or "I know that the sun in Ottawa does not shine at midnight."

There are at least two observations to make about the senselessness of doubting or claiming to know that, for example, the sun does not shine in Ottawa at midnight. The first is that there are a range of doubts which would be considered hollow, not the sign of someone who was being shrewdly cautious, but of someone who had not yet learned, or had not learned properly, what it means to doubt. Wittgenstein asks us to image a pupil who will not let anything be explained to him because he continually interrupts with doubts, for instance as to the existence of things, the meaning of words, etc.. The teacher says to him "Stop interrupting me and do as I tell you. So far your doubts don't make sense at all."41 The doubts of the student are hollow. This is one kind of general doubt that might be uttered about the sun in Ottawa. A student who constantly interrupted his history lessons with doubts as to whether the earth really existed would be raising doubts that are not germane to the discipline of history. If he continues to raise these hollow doubts despite the discipline of the teacher, he will not be capable of settling long enough to acquire the practice. Such a student might eventually be dealt with as a discipline problem. If he acquires elements of the discipline of history but remains unable to make the fine discernments about which doubts open up fruitful lines of inquiry, and boisterously continues to raise inappropriate doubts, he will likely be regarded as a loose cannon. Motives and causes will be sought for the behavior that distracts so much attention from the quest for discerning grounds for doubt. If a party were to come to court raising these kinds of doubts at every turn, either a motive would be sought (for example, obstruction of justice) or she would be disciplined, like the student who constantly interrupts, as she clearly does not grasp, nor want to grasp, procedure in a court of law.

There is another possibility about things like the possibility of the sun shining at midnight in Ottawa or centipede horses related to the discipline of the courtroom. These are special circumstance doubts that evoke Hilary Putnam's possible worlds experiments. Putnam, in an early analysis from which he has since retreated, attempted to maintain the hypotheses that the natural world had essential elements which scientists discover and which, like Moore's metaphysical certainty arising from immediate sense data, should serve as a foundation for certifying our more ordinary beliefs. He imagined what would happen if a scientist

${ }^{41}$ Ibid. at $\$ 310$. 
developed a new test and discovered that, for example, a large part of what we have been calling 'gold' in fact turned out to have the chemical composition of fool's gold. We would not, he claimed (and probably with reason) say that true gold, it turns out, also has the chemical composition of fool's gold. We would say that much of what we had been calling gold up until that point in fact turns out to be fool's gold - and the price of gold would go up. The chemical composition of pure gold is - or has become - to a very large extent, determinative of what we mean by the word "gold"; is "of the essence" of gold.

Putnam then went on to imagine a world where another planet was discovered on which there was a substance that looked like water, that people from earth could drink and bath in, that fell from clouds and filled lakes and ponds, froze at $0^{\circ} \mathrm{C}$ and boiled at $100^{\circ} \mathrm{C}$, that had all of the properties with which we are familiar here on earth and behaved in the same manner as what we call water - even when transported in large quantities to earth. Suppose that after years and years of calling this substance "water" scientists discovered that in fact it had the chemical composition $\mathrm{K}_{2} \mathrm{O}$ rather than $\mathrm{H}_{2} \mathrm{O}$. Putnam claimed, on the same model as the fool's gold example, that we would (and should) defer to the experts and say "we have always thought that substance from the other planet to be water but now we know that it is not". But on this example, it is not clear that we would defer to expert scientific opinion. We might just as easily say: "we have always thought that the chemical composition of water was $\mathrm{H}_{2} \mathrm{O}$, but now we know that water has various chemical compositions". There are some words whose meaning is so tightly wound up with common language and ordinary experience that we do not privilege experts to determine what they really are. For some words, the determination by experts is, or has come to be, such an integral part of their meaning that we defer. Gold might be an example. But for other common and familiar words and objects we do not. Hence if a geneticist were to declare to have found that what we have been calling centipedes in fact had the exact genetic characteristics of what we have been calling horses, we would not now call horses four-legged animals and hundred-legged insects; we would say that we have discovered centipedes with the exact genetic characteristics of horses. Genetic science would be revolutionized by such a discovery before ordinary usage would. Common usage and meaning would prevail. Science is a specialized discipline, like history, and both are predicate upon the scientist and the historian having first mastered ordinary language and the common sense and ordinary experiences that they share with us. The mastery of these specialized crafts depends upon the prior mastery of a common language. These kinds of doubts, like doubts about the existence of the earth, would be excluded from procedure in a court 
of law because for the doubts to be reasonably raised, the speaker must already have taken for granted a world of shared meanings that, if thrown into doubt, would simultaneously throw into doubt the entire enterprise of science or history.

It should now be easier to recognize the grammatical errors to which Thayer and Davis seem vulnerable. The view they promote of the takenfor granted background of evidence law's foreground of proofs is susceptible to the same critique of G.E. Moore's foundationalism that Wittgenstein mounted. When they claim that judicial notice is taken of those unproven assumptions upon which proof is predicate such as the ordinary meaning of words and the fact that rain runs downhill, there is a sense in which they are saying something akin to "I know this is a hand." The idea that these are assumptions constantly being made through some unconscious mental process, like William James' stream of consciousness, is as misguided as Moore's contention that he was saying something intelligible when he uttered his famous words. It would be incoherent to say, in the process of a trial, that, for the purpose of this dispute, I shall assume that the words of the English language have not changed since yesterday, or I shall assume that the court building has not been moved by spacemen to France subjecting proceedings to that jurisdiction's rules of evidence or I am assuming, for the purposes of this trial, that all of the parties to the proceedings are not robots created as part of a technological experiment by a secret joint academy of science and law. This would be as unintelligible as a mathematician who said "For the purposes of making this calculation I shall assume that the figures do not shift about on the page." The notion of an assumption in mathematics functions more like this: For the purpose of this calculation, I will assume that theorem $\mathrm{X}$ is valid. It would be close to impossible to imagine what would constitute proof against the proposition that numbers shifted on the page or that the English language was susceptible to change overnight or that spaceships might move courthouses into different jurisdictions. It does not make sense to say that judges are constantly taking judicial notice of an infinity of taken-for-granted, undoubtable things. It does not make sense to claim that judges know or are perpetually assuming these things if it does not make sense to raise doubts against them. The idea of "taking judicial notice" is idle if this is what Thayer and Davis mean by it. It does no work at all. Like Moore, they would be wrong in thinking that a judicially noticing judge is assuming all of these things, not because the assumptions are false but because the claim that they are assumptions is grammatically incorrect.

This argument might appear to be decisive against the Thayer/Davis doctrine. I do not believe that it is. It can be rescued in two ways. The second takes the direction of recognizing that special circumstances can arise in which it makes sense to doubt common sense. The first revision 
is to reformulate their view of things which "everybody knows" or "reasonable people assume" to read rather as things which are understood. These are what I have preferred to call "forms of life" matters or agreements in judgment or agreements in understanding rather than unproven facts or propositions or assumptions. And a compelling reason exists for preserving the Thayer/Davis doctrine of implicit judicial notice, one that the Moge recognition of the feminization of poverty would find congenial.

The first revision to the Thayer/Davis doctrine is to shift from talking about "knowledge" or "assumptions" and to talk, instead, about understanding or agreements in judgment. These are things that are susceptible to what I have called "form of life" judicial notice. There is a way of construing this category of "things which are taken-for-granted" which does, and should, turn wheels in the legal machinery. It begs for the continuation of the notion of tacit judicial notice, both as recognition that some form of "taking judicial notice" happens implicitly and as a recognition that, contrary to Delisle's claim, the demand for explicit procedure does not always operate in the service of natural justice. ${ }^{42}$ Ignoring the scope of "form of life" judicial notice would foreclose critically important appeals from things which the judge simply, and unjustly, took-for-granted. And Wittgenstein pointed out a way to articulate this concern.

Moore thought that he had found a foundation on which to refute the sceptic's doubt about the existence of the external world. He was searching for" a kind of super-certainty or metaphysical certainty. Wittgenstein argued that his thoughts were delusional. He borrowed the concept from contexts in which the words "I know $X$ " are meaningful and used them in a context where they were not. He was merely uttering the same words without their having a sense. But Wittgenstein makes another point that is very close to Moore's foundationalism, but not quite. He remarks: "I should like to say: Moore does not know what he asserts he knows, but it stands fast for him, as also for me; regarding it as absolutely solid is part of our method of doubt and enquiry." asserts that some things are solid, this sounds like a foundationalist statement. And in a sense it approaches one. Yet these are not things that are amenable to either doubt or knowledge. Rather they are the things that formed part of the background of the learning process. They are not exactly foundational, however, because it is conceivable that another people, for example, might not have taken precisely the same things for granted as they inculcated their young into practices and beliefs and it is

\footnotetext{
${ }^{42}$ Supra note 19.

${ }^{43}$ Wittgenstein, supra note 38 at $\S 151$ [emphasis added].
} 
also possible that these things are only foundational for human beings living in the kind of world in which we live. It is possible, for example, that a people exists who groundlessly believe, just as groundlessly as we believe the contrary, that things disappear into thin air. We could elaborate a picture of a community that incorporated this understanding into all of their transactions and relationships. Regarding these matters as absolutely solid and commonsensical should not be amenable to proof or disproof as they constitute part of the very method of doubt and enquiry. "That is to say," Wittgenstein remarks, "the question that we raise and our doubts depend on the fact that some propositions are exempt from doubt, are as it were like hinges on which those turn." ${ }^{, 4}$ The solidity of these matters arises from similarities in training rather than similarities in opinion.

But that does not necessarily mean that these background matters are utterly and always exempt from doubt. The hinges about which opinions and assumptions turn may not be the same hinges for people who do not share similarities in training. While a court may be taking judicial notice implicitly of these taken-for-granted matters that constitute our form of life, may be precluded from even recognizing their artificiality and the fact that they arise from similarities in training, and may indeed take them as elements of the natural world, an outsider to the practice may quickly recognize how arbitrary and conventional those beliefs actually are. Cultures only appear from the point of view of an outsider. From the inside, they are simply the way that things are done.

As Bourdieu remarks, "Every established order tends to produce the naturalization of its own arbitrariness." 45 It is this misrecognition of its own arbitrariness - the inability of participants to perceive their sensibilities as one possible tradition among others - that gives participants their sense of reality. And it is precisely this arbitrarily entrenched sense of reality - the hinge upon which turn the questions we raise and upon which our doubts depend - that are susceptible to tyrannizing someone raised with different experiences and in a different tradition. It is for this reason that the Thayer/Davis doctrine of implicit judicial notice and its implications for appeal as well as the concomitant openness of judicial notice to dispute as prima facie evidence, are worth preserving, for they keep open the possibility of recourse from the tyranny of one group's common sense.

"Form of life" judicial notice functions in these cases to shift the field of that which will be amenable to doubt, to knowledge, to belief, and to opinion. As Bourdieu remarks "opinion ... [is] one of the different

\footnotetext{
${ }^{44}$ Ibid. at $\$ 341$.

${ }^{45}$ P. Bourdieu, Outline of a Theory of Practice (Cambridge: Cambridge University Press, 1977) at 164 [hereinafter Bourdieu].
} 
and equally legitimate answers which can be given to an explicit question." ${ }^{46}$ This domain of opinion and argument would be a good place to locate Monahan and Walker's social framework facts which are open to research, new evidence, scientific criteria of proof. It would be fair to say that social framework facts are based on assumptions. There is, however, a line drawn between the field of opinion - of that which is explicitly questioned - and the field of doxa (as Bourdieu calls it) that which is beyond question, which goes without saying because it comes without saying, which each agent tacitly accords by the mere fact of acting in accord with social convention. "Form of life" judicial notice takes the latter for granted in setting constraints on the range of legitimate answers or credible opinions. Drawing attention to the arbitrariness of the form of life attempts to move, if only incrementally and over time, different things into the naturalized background. Drawing attention to the misrecognition of arbitrariness thereby shifts the range of legitimate and credible opinion onto the foreground.

It is important to note here that this is not a matter of changing people's assumptions and entering new facts or propositions into those things that "everybody knows" - or at least not only a matter of this. It is more a matter of shifting the underlying agreements in judgment about what will constitute legitimate opinions and answers and doubts and those things, like madness or loose cannon behavior, that we do not seek to modify by presenting reasons for or against as we would for a mistake, but for which we look for causes and motives. Judicial notice in these cases looks more like matters of judgment than like matters of fact.

This challenge to the established order's sense of reality is not unlike one of the ways in which the judicial notice of the feminization of poverty operates. It seeks to establish a new orthodoxy, recognizing that prior understandings of the unremunerated gift economy of the family were hinged upon things that go without saying because they come without saying, those things "which each agent tacitly accords by the mere fact of acting in accord with social convention." ${ }^{47}$ Judicial notice of the feminization of poverty in determining spousal support orders exposes the arbitrariness of the taken-for-granted, in this case that women's labour in the home is appropriate behavior - appropriate to womanhood. Childcare and domestic labour take on their social meanings and values from a domain of tenderness wholly incommensurable with market values and considerations which, in turn, flow from a domain wholly incommensurable with considerations of tenderness.

\footnotetext{
${ }^{46} \mathrm{Ibid}$. at 168 .

${ }^{47}$ Ibid. at 169.
} 
It did not escape Davis that judicial notice is often a matter of judgment. Indeed it is this quality which inspired him to claim that judicially noticed matters should be open to dispute. In reflecting on a case in which the court relied upon a common sense of reality for its holding he asks:

Was the court right in speaking of "the plainest facts of our national life"? Or was what the Court called "facts" in truth judgment? Or was it a mixture of facts and judgment - an interpretation of facts? ... The answer to these questions probably is that the observations were factual but were inseparably mixed with judgment, that the mixture of facts and of judgment was by no means indisputable, and that judges cannot think without constantly using such mixtures of facts and of judgment, even though the mixtures are often far from indisputable. ${ }^{48}$

Bedrock has been reached in these cases where what is in issue are forms of life. We reach the end of giving reasons because these are the background things with which we reason, the hinges upon which turn the questions that we raise and upon which our doubts depend. There is nothing, or not very much, that can be said to convince someone who does not share a similarity in training with us. We say at this point "this is what we do".

The notion of discipline discussed above in regard to someone who kept interrupting a history lesson with doubts as to whether the earth really existed is apt. The teacher does not "know" the earth exists, nor "assumes" it, nor can even be correctly said to "believe" it. An idly doubting student would be disciplined because in order to learn the practice, she must first be obedient and accept the authority of standards and the inadequacy of her own performance as judged by them. Because these are things not, in general, amenable to "doubt" and therefore not amenable to "knowledge", they are not facts. They are judgments, grounded in similarities in training.

This type of judicial notice operates authoritatively then. But this is not an authority that need necessarily trouble us. Without question it is an ultimately arbitrary authority in the sense that it is grounded in nothing more metaphysically certain than a community of human beings similarly trained into a language of social meanings. But the fact that judicial notice is, at bedrock, arbitrary, does not mean that it is necessarily a display of force or an exercise in tyranny.

The court's judgments about judicial notice may not be displays of force, but displays of power or authority in the sense that Michael Walzer

${ }^{48}$ Davis, supra note 10 at 951. 
distinguishes between force and power. "Force," he remarks, "is power used in violation of its social meaning." court, I have suggested above, arises in a manner not very different from the manner in which an expert acquires his or her authority. She acquires it not through the democratic process, not because she articulates a consensus or even represents a majority opinion in the community, but because she is seen to have been obedient to the attitudes, choices, preferences and forms of reasoning which currently and partially define the practice of law. Having originally accepted the inadequacy of her own performance as judged by those community standards she may excel and generate, through diligence, devotion, and brilliance, one of those formulations which become the best standards realized so far. In that event the expert will speak superlatively for the community, not for him or herself. This would be the authority of the court operating within its social meaning. In all of the examples I have used about centipedic horses and doubts about the existence of the world, MacIntyre's comment that "A violation of the bonds of the community ... has to be recognized for what it is by the community, if the community is not itself to fail" is apt; and for a range of violations of social meanings the legally trained judge is the one whom we have qualified to recognize and pass judgment upon those violations.

This analysis is the first revision of the Thayer/Davis doctrine that I wanted to argue. For there is room to recognize that the court must operate with community judgments as a background or "form of life" for its tableau of proofs on the foreground. Ordinarily this background is taken-for-granted and is implicitly "noticed". This background is not amenable to doubts without grounds. But a very significant doubt can be raised by a group who argue that they do not share the similarities in training which give the court its second nature and that the misrecognition of this arbitrariness has led to an injustice. In general, the court cannot be expected to notice its own misrecognition of arbitrariness. Therefore that the court has 'taken notice' will be something that arises on appeal or directly as an argument about how forms of argument congenial to the court's way of doing things are hostile to the very "form of life" of a particular community.

There is a further implication of this recognition that judicial notice operates as a judgment authorized by the social meaning of the court and that it is legitimately contested by alternative forms of life in the political community with social meanings at variance with the court's. The court's authority to discipline extends to expressions of idle doubt and utterances

${ }^{49}$ M. Walzer, Spheres of Justice: A Defense of Pluralism and Equality (New York: Basic Books, 1983) at 282. 
of doubt for which causes and motives rather than reasons should be sought. In the case of idle doubts and motivated utterances of doubt, the criteria of elimination would be that the doubter is not responding to any practice in which doubts might be rendered intelligible. They are a loose cannon like the student who interrupts the history lesson with doubts about whether the earth really existed. Because these doubts are hollow does not entail that belief in history might be hollow. The party has not learned what doubts count within the discipline of history.

Judicial notice as an exercise of authority grounded in social meanings generated by the political community could have eliminated Zundel's highly motivated - that is caused rather than grounded speculations on this basis. ${ }^{50}$ Charged with spreading false news by publishing material that denied the existence of the Holocaust, Zundel argued that the historical fact was not amenable to judicial notice - not being, for him, a fact. The trial judge did not operate his discretion to take notice, a judgment supported on appeal, arguing that the Holocaust was, at least in this instance, a contentious historical fact which the Crown had to demonstrate in proving that specific statements or allegations in Zundel's publication were false. But the core contention that excluded it from "what everybody knows" was the speculation of the accused. By opening up a pivotal historical understanding of the $20^{\text {th }}$ Century to proof and demonstration, a considerable load of the court's socially constructed authority was lent to confirming the rational legitimacy of Zundel's speculations, moving them from the realm of idle and motivated assaults upon conventional wisdom. By refusing notice the court was implicitly affirming the opposite: that the occurrence of the Holocaust was open to a speculation which Canadian courts were prepared to entertain, was not notoriously true and beyond dispute, and that the reasonable person might be wiser to think twice. Zundel's speculation became "one of the different and equally legitimate answers which can be given to an explicit question." 51 It is not evident that the political community gave the court this authority.

Another argument is available against Zundel's motivated speculations from the "form of life" understanding of judicial notice. By analogy with the Putnam examples, there are certain understandings of the world upon which we will not allow experts to overrule us. Those are the kinds of understandings upon which the very enterprise of the expert is founded, understandings which, if undermined, should throw into disarray the ordinary world of the political community through which all disciplines acquire their authority. This is another sense of MacIntyre's comment that "a violation of the bounds of the community ... has to be

\footnotetext{
${ }^{50} R$. v. Zundel (1987) 31 CCC (3d) 97 ; R. v. Zundel (1990) 53 CCC (3rd) 161.

${ }^{51}$ Bourdieu, supra note 45 at 168.
} 
recognized for what it is by the community, if the community is not itself to fail." The legitimate authority of the court is borrowed from its social meaning, a meaning which, like the expert's testimony, is not self-made. The fact that a democratic legislature has created legislation against hate literature goes to evidence about the accepted social meanings that the court is authorized to enforce, is evidence about the nature of the political community that founds its authority. The court's failure to recognize the violation of these ordinary bonds of the community - the ordinary world of the political community from which the discipline of history and law get their authority - was a failure of both the political community and the court's authority. Had judicial notice been granted in Zundel rather than proof been required in reliance upon the credibility of expert testimony, this use would have been close to the Morgan doctrine of the authoritative judge declaring indisputably that the fact of the Holocaust was so notorious as not to be the subject of dispute among reasonable persons, declining to further grace an idle and motivated speculation by responding to it with reasons certified by credible experts.

I draw these analogies between the Zundel case and the motivated idle skeptic in order to distinguish them from the second way in which the Davis/Thayer doctrine of judicial notice can be rescued from the vacuity to which it is prey. The second way to rescue the doctrine is to note that although idle doubts are eliminated and concomitant claims to knowledge rendered senseless in the face of idle doubt, there are special circumstances in which common sense might be open to doubt. In many instances, nobody raises a question about the ordinary meaning of words or whether rain runs downhill or whether there is sun in Ottawa at midnight. No doubt has been raised, therefore these are the kinds of statements in which first of all it is not unintelligible to claim that they are "assumed" or that "everybody knows them to be true" in the same way that Moore's utterance "I know that this is my hand" is without meaning. Adding to their vacuity is the fact that no party has raised a contingent doubt about them. They are doubly idle utterances upon which the doctrine of judicial notice loses credibility if it claims to notice them.

But the fact that in unspecified and general circumstances certain propositions are meaningless and turn wheels idly does not mean that in all circumstances they will be vacuous. This is the point of the argument above that special circumstances might arise in which it makes sense to both doubt and to claim to know things like that a car traveling eighty miles per hour cannot stop within a distance of ten feet, that the gun is a dangerous weapon, that a horse is a four-legged animal, and that the sun does not shine at midnight in Ottawa. Those special circumstances would be the ones to which a party in a dispute raises a doubt about common 
sense. The factual situation of one of the parties to the dispute gives rise to doubts about common sense, ordinary usage, and what "everybody knows". In this case, the facts in consideration are, to use Davis' variable, close to the center of the controversy between the parties. It would not be sufficient to raise these doubts by simply directing aimless attacks at the infinity of things that are taken for granted if they are not relevant to the parties at hand. They would only work on the adduction of a very specific scenario. I would call these cases "special circumstance" judicial notice to distinguish them from "form of life" judicial notice. They merit different procedure and different analysis, the former calling for explicit notice of prima facie evidence, the latter being implicit notice amenable to dispute on the basis of contending loci of social meaning.

But if the reasons for doubting common sense are close to the center of the controversy between the parties, then they are open for dispute. It would make sense to treat the judgment implicit to judicial notice as inconclusive prima facie evidence rather than to authoritatively foreclose debate. This test of closeness to the center of controversy between the parties is similar to the one that the court used in Zundel in refusing to give judicial notice to the fact of the Holocaust. They used it erroneously, in my opinion, for no remotely convincing counterfactual scenario was presented which would have prompted the kind of judge whom we have authorized to recognize violations of the community to have second thoughts.

Judicial notice in "special circumstance" notice would play a role very similar to that which Morgan advocated. Having heard contextual arguments pleading against common sense that would ordinarily read phrases like "guns are dangerous weapons" or "I know this is my hand" to be empty and senseless, the judge could determine that the scenario presented does not, in fact, raise sufficient grounds to give the scenario a meaning. If, in the judgment of the judge, the special circumstances have raised an idle or motivated doubt the judge is authorized, for the sake of expediency, to scoop the contention out of the arena of proof and disproof and immunize it from further dispute save those raised on appeal.

Having drawn attention to a certain vacuity in the Thayer/Davis doctrine, I have tried to rescue it by replacing "assumptions" and "that which everybody knows" with the "form of life" in which law makes sense. I have also tried to rescue the disputability of judicial notice that Thayer and Davis wanted to retain by noting that those special circumstances in which either one form of life contests another or in which particular scenarios have arisen to throw common sense in doubt, are precisely those in which the dispute is so close to the center of controversy that it would defy natural justice if a mechanism were not built into the machinery of law for these contentions to find a voice. With 
these revisions, I am now more equipped to inquire as to whether the Thayer/Davis doctrine of judicial notice has received judicial notice in Canadian law and whether the conventional wisdom upon which legal commentators and judges ground their authority has come full circle since Morgan wrote his treatise half a century ago and had his thinking permeate the law.

\section{Has Thayer's. Doctrine of Judicial Notice Received Judicial Notice?}

On the Thayer doctrine of judicial notice, as developed by Davis, Monahan and Walker, and L'Heureux-Dubé, judicial notice does not operate in a significantly different way than stare decisis. Judicially noticed facts are incorporated into the common law as law thereby guiding future cases in requiring departures to be justified and also thereby serving to consolidate the integrity of the legal system. As law, judicially noticed facts are open to appeal where ordinary facts remain within the jurisdiction of the court of first instance. As law, they also open the theory of sources up to extra-legislative and extra-judicial sources of law. Diverse communities within the political community are the sources of these judicially noticed legal facts which are certified by experts who have qualified themselves to speak superlatively to standards of excellence and accepted understandings of a community pertinent to the dispute at hand. Judicially noticed facts serve as prima facie evidence open to rebuttal by changes in community standards or understandings on the judicially noticed facts, directly by dispute by one of the parties to the litigation, and on appeal. With the qualifications I have added concerning "form of life" judicial notice, noticed facts are also amenable to dispute by communities contesting relevant forms of life of the court at any level of the proceedings. With the qualification that I have raised on the Davis/Thayer doctrine which eliminates vacuous forms of notice, "taking judicial notice" implicitly should be retained as part of the doctrine. Judicially noticed facts are not significantly different from judgments and the authority for the court's judgments comes not from democratic process but from the court continuing to exemplify the social meaning which the political community attributes to the court in the same manner as different communities do their experts. Is this version of the doctrine conventionally wise? Is it good legal practice?

I will concede that the following argument is open to dispute but will nonetheless lay out the prima facie evidence. The social meaning of the court in Canada includes the presumption that judges act either as authorities on the law (stare decisis) or are familiar with the most authoritative sources of the law. L'Heureux-Dubé in her office as Supreme Court justice is in a position to make authoritative statements 
about the law. If her obiter on judicial notice were not obiter but were ratio decidendi, the Moge decision on its own would have changed the doctrine to accord with Monahan and Walker's analysis. As it is, her obiter on the feminization of poverty has, in fact, been taken up by lower courts and treated precedentially. The practice of lower courts has incorporated the obiter into the common law, which, on the social meaning of legal practice, it is qualified to do. In her office as a legal commentator, enhanced by the authority of her Supreme Court office, she stands as close to the pinnacle of making authoritative statements about the law as Sopinka in his alternative textbook version of the doctrine, versions that not only have been incorporated into Supreme Court decisions but that also tacitly license the ability of legal commentators to speak authoritatively about the law. L'Heureux-Dubé's legal commentary consolidates the conventional wisdom of the Thayer/Davis doctrine. Legal practice subsequent to Moge has further incorporated the authority of her version by treating the feminization of poverty as prima facie evidence, thereby consolidating the change in conventional wisdom that her article tentatively, but boldly advanced.

These developments cannot be perceived, or assumed, or acknowledged as acts of power used in violation of their social meaning until non-idle, non-motivated reasons are advanced to raise a doubt. Reasons that count would be responsive to the actual practice of law within the Canadian political community. This implicit understanding of the practice of the court is open to debate should a relevant understanding of the political community, responsive to a compelling counter-history or counter-tradition be advanced to provoke the practice of law out of its taken-for-granted misrepresentations of its own arbitrariness. Or it is open to debate should a diligent, devoted, and perhaps brilliant expert arise whose formulation is judged to so well encapsulate the tensions which reflect unarticulated agreements in judgement in the community that it becomes the best standard realized so far.

On the basis of these observations I would contend that the Thayer doctrine has been incorporated into the common law as a guide to future cases. This both puts the onus on future cases to justify their departures and also serves to consolidate the integrity of the legal system. Judicial notice, I would add, plays a critical and often implicit part in the form of life that gives both the court and the legal system their social meaning.

I will coyly conclude by adding that if Thayer's doctrine of judicial notice has been recognized in Canadian law and its renewed ascendancy is the subject of ongoing debate about the nature and place of the doctrine, then his sense that judicial notice is woven into the very texture of legal reasoning will be confirmed, for the strength of that very texture is bold but tentative claims to knowledge backed by similarities in 
training and open to persuasion and dispute. This, I will boldly and tentatively assert, is the warrant that puts the doctrine of judicial notice at the very beginning of a treatise on evidence as a clear and distinct warning that it has a place wherever the process of reasoning has a place. And that, as Thayer asserted, is everywhere - as we understand everywhere to be.

\begin{abstract}
The doctrine of judicial notice has been gaining attention in Canadian jurisprudence. This article begins with an examination of how the doctrine has been recently used in areas such as family law to bring a diversity of community interests into the legal decision-making process. The history of the doctrine in American and Canadian jurisprudence is reviewed along with its principal characterizations in the works of Thayer, Morgan, and Davis. The article goes on to uncover several epistemological problems to which the doctrine is prone and proposes a means of getting out of these philosophical dilemmas while keeping the integrity of the doctrine intact. The article concludes by alluding to the communitarian uses to which the doctrine might be put.

\section{Résumé}

La doctrine de la connaissance judiciaire attire de plus en plus d'attention dans la jurisprudence canadienne. Cet article analyse d'abord comment la doctrine fut utilisée dans des champs comme celui du droit de la famille pour introduire divers intérêts communautaires dans le processus de décision judiciaire. L'histoire de la doctrine dans la jurisprudence américaine et canadienne est revisitée par rapport aux principales lignes de pensée exprimées dans les oeuvres de Thayer, de Morgan et de Davis. L'article débusque ensuite plusieurs problèmes épistémologiques auxquels la doctrine se prête et propose une voie pour sortir de ces dilemmes philosophiques tout en préservant son intégrité. Il conclut en soulevant les utilisations communautaires possibles de cette doctrine.
\end{abstract}

\author{
Susan G. Drummond \\ Osgoode Hall Law School, \\ York University \\ 4700 Keele Street \\ North York (Ontario) \\ Canada M3J 1P3
}


